\title{
Analysis and Research on the Cultivation of Applied Talents in Local University or Colleges
}

\author{
Xingliu $\mathrm{HU}^{1, \mathrm{a}^{*}}$, Haifei $\mathrm{SI}^{1, \mathrm{~b}}$, Zhong Yang ${ }^{1, \mathrm{c}}$ and Yujuan Tang ${ }^{1, \mathrm{~d}}$ \\ ${ }^{1}$ Full address of first author, including $\mathrm{cou}^{1}$ College of Intelligent Science and Control Engineering, \\ Jinling Institute of Technology , Nanjing, Jiangshu, 211169, China; \\ axinghu8@163.com, bsihaif@jit.edu.cn, cyz@jit.edu.cn \\ dyjtang@jit.edu.cn \\ ${ }^{*}$ Corresponding author
}

Keywords: Applied talents, Local university, Research, Training model.

\begin{abstract}
The idea and strategy of training applied talents in local colleges and universities is analyzed in this paper. It is necessary to strengthen the research on the social needs of applied professionals and study the training standards for undergraduate applied talents. The talent training model is needed to reform by clarifying the orientation of schools. Establishing the application oriented curriculum system based on disciplines, strengthening the construction of teachers, and reforming the talent training model are some main strategies of cultivating talents. It is important to develop a talent training program that meets the characteristics of the university and improve the quality of applied talents.
\end{abstract}

\section{Introduction}

Under the background of new teaching reform, strengthening the scientific implementation of talent training in local universities is an important measure to promote China's overall economic development.

At present, as far as china's current talent size and structure are concerned, there is a relative lack of applied undergraduate talents. From the perspective of China's overall talent market, the overall talent demand of the society is not connected with the scale and quality of the talents provided by the university. China's talent structure is still not suitable for the needs of industrial structure, and there is a shortage of actual high-skilled talents.

Therefore, in the face of the reality of the diversification of talent demand in the society, it is necessary to comply with the situation of economic development, follow the rules of education and teaching, update the teaching concept, actively explore the application-based undergraduate talent training model.

\section{The type of talent}

The type of talent that society needs is determined by the different needs of social development. The talents who study objective laws is needed by the society. the talents who use objective laws and scientific principles to transform the world and create direct benefits for human society is also needed.

These two types of talents should have different emphasis on training specifications. Research-oriented talents focus on cultivating their ability to discover and explore objective laws and innovate knowledge. Application-oriented talents focus on cultivating their applied expertise to actual production, especially in transforming high-tech knowledge into productivity (including management and service capabilities). The ability is to create direct benefits for society.

Many local colleges began to cultivate the applied talents for local economic and social development. This kind of transformation is actually the result of painstaking thoughts of such 
colleges and universities. It is a rational return of new undergraduate colleges to meet the needs of society and improve the quality of personnel training.

\section{The ability structure of applied talents}

The main task of application-oriented talents is to apply scientific principles directly to the field of social practice, thus creating direct economic benefits and material wealth for the society. The core of applied talents is application which is the foundation of knowledge and ability. The purpose of application is to meet the social demand, promoting social progress. The ability structure of applied talents are as Fig.1.

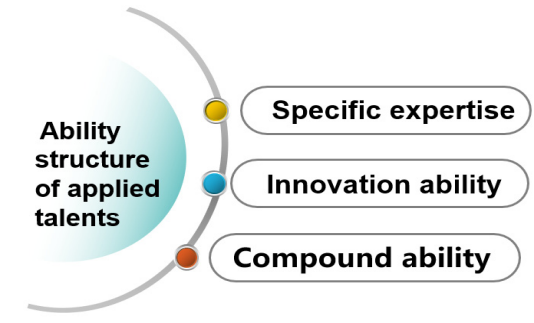

Fig. 1. Ability structure of applied talents

\subsection{Specific expertise}

Application-oriented talents should be familiar with the working procedures and methods of industries, that is, professional practical skills. This kind of practice ability is necessary to students to do a professional job, its specific content and requirements for different industry, each industry has some special professional skill.

Heterogeneity is firstly determined by the professional characteristics of engineering and technical majors. Engineering talent or technical personnel can solve the technical problems in specific engineering projects, fine operation and other business skilled craftsmen. This requires the proficiency of equipment installation, commissioning, machine maintenance in the industry field.

\subsection{Innovation ability}

Innovation ability refers to the ability that pursue new ideas, new designs, and solve problems with new methods and solutions. Application-oriented talents must have a strong sense of innovation. Only a strong sense of innovation, can they produce strong innovation incentives. If the innovation goal is set up, their potential creativity love and dedication to pursue their career can be played as much as possible.

According to human resource theory, human capital investment is an important way to realize national competitiveness and personal competitiveness. From a personal point of view, applied talents training is a kind of education investment for individuals, one of the main motives of applied talents education is personal competitiveness through high-level personnel training, and then get the higher level of employment opportunities and sustainable development ability. The embodiment of this ability is the ability to deal with 'uncertainty', it is a kind of ability to create new value.

\subsection{Compound ability}

Job depends on the power of the community, and individuals need to communicate effectively to promote the development of the cause. Therefore, application-oriented talents need to strengthen their own personality cultivation, cultivate a sound personality, enhance the charm of personality and the ability to live together and cooperate with others. The ability to cooperate with others is also a reflection of its own competitiveness.

The purpose of the study is to apply technology to practice in order to solve the practical problems. At the same time, the applied talents that are needed by industry and enterprise are skilled professional talents. The systemic capability is the core to solve the problem of project requirements, consciousness and innovation ability are competitive requirements. The corresponding capability 
structure of these requirements is hierarchical and complex, which is the core competitiveness of applied talents in the new era.

\section{The characteristics of APPLIED TALENTS}

The characteristics of the application-based undergraduate talent training are mainly reflected in the following aspects. With the diversified needs of talents for economic development. The scale of college education is expanding and the types of education are increasing. The training mode of applied undergraduate talents in colleges and universities in China gradually moves from a single direction to diversification, different universities adopt different talent training models. The characteristics of applied talents are as Fig.2.

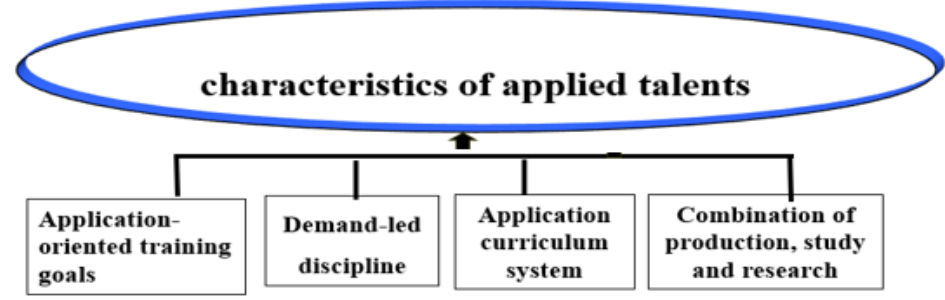

Fig. 2. Characteristics of applied talents

\subsection{Application-oriented training goals}

It is the basic requirement for undergraduate talents to master the basic theories, expertise and basic skills of this subject. Application-oriented talents are paid more attention to the cultivation of applications than academic talents. Application can be described as its core embodiment. Applied undergraduate talents are mainly oriented to social needs, require strong professional application ability, and can directly adapt to the needs of the corresponding occupations and positions in society.

The transformation and development of local colleges and universities and the ultimate goal of talent growth training are synergistic. The ultimate goal of talent development is to gain comprehensive application capability, so as to achieve employment of talents.

\subsection{Demand-led discipline}

The development of applied disciplines is focused in china's applied undergraduate talent training mode. Applied undergraduate talents are mainly cultivated by local undergraduate colleges, while local undergraduate colleges mainly serve the local economic development based on local social needs. They are adapted to the needs of local economic and social development. Trends in the economic and industry expertise are closely related. Local colleges and universities should investigate the actual economic and social development of the region, adjust the structural problems of the disciplines according to the direction of their talent.

\subsection{Application-oriented curriculum system}

The curriculum system based on subject and application-oriented mainly not only refers to the basic knowledge of the subject but also the development of students' professional application ability. Applied undergraduate talent training doesn't emphasize the professional application skills alone, the basic knowledge of the subject is also very important. As the social problems become more and more complex, the study of interdisciplinary theoretical knowledge is necessary. It is necessary to rely on several related disciplines to enable students to Interdisciplinary basic knowledge to cultivate composite application talents. In terms of application-oriented, China's applied undergraduate talent training mode has developed to a certain extent around the theoretical and practical courses of professional application ability, course content, teaching methods and assessment methods. 


\subsection{The combination of production, study and research}

The combination of production, study and research education is an effective model for cultivating innovative application-oriented talents. The characteristics of the cooperation among industry, university and research institutes in applied undergraduate colleges are mainly based on learning and supplemented by research. That is, students should participate in practical work in enterprises or institutions to improve their practical ability, and participate in research and improve scientific research ability.

\section{Summary}

Talent cultivation is the foundation of the school, and teaching is a top priority. Local universities and colleges should strengthen the central position of personnel training, further clarify the ideas and tasks of teaching work. The measures and ways of talent training should be further considered. The overall requirements of connotation development, strength improvement, and distinctive features should be adhered to. The student-centered education concept should be implemented to promote the reform of the application-oriented talent training mode. Facing the new social and economic development environment, local colleges and universities have the responsibility to meet the needs of market talents, which requires the application of talent training objectives will be further strengthened.

\section{Acknowledgment}

This work was supported in part by the Ministry of Education's Cooperative Education Project under Grant 201701056001, 201801112066,Jinling Institute of Technology's Education Reform Project under Grant 2017JYJG03, National Science Foundation of the Higher Education Institutions of Jiangsu Province under Grant 15KJB520010,Qing Lan Project, Jiangsu Province' s Natural Science Foundation under Grant BK20171114,A joint prospective industry-University-Research Collaboration project of Jiangsu Province under Grant BY2016012-02, Jinling Institute of Technology's Research Training Project under Grant Jit-fhxm-201606.

\section{References}

[1] D.B.Chen, and F. Yang, "Reform and Practice of Experiment Teaching for the Cultivation of Applied Talents ," Experiment Science \& Technology, vol. 4, pp. 15-19, 2010.

[2] FU, Xing-feng, et al, "Construction of the Practical Teaching System for Cultivating Applied Talents ," Research and Exploration in Laboratory, vol. 6,pp. 42-46, 2011.

[3] Y.Wu, and L.W.Wang, "The Teaching Reform of Algorithm Design and Analysis in the Training Mode of Applied Talents,"Computer \& Telecommunication, vol. 3, pp. 75-76, 2017.

[4] Jun, Dong, et al,"Innovation and Practice of Training Program for the High-quality Applied Talents of Optoelectronic Information Science and Engineering Discipline,"The Science Education Article Collects, vol.4, pp. 25-29, 2015.

[5] X.M.Zhang, "Engineering Education Philosophy Leads the Training Mode of Innovative Talents_- The Exploration and Practice on Implementing Outstanding Engineers Education Training Plan ," Higher Education in Chemical Engineering, vol. 3, pp. 2-7, 2017. 